\title{
Physiological Activities of the Neem and the Comfrey Extracts as Cosmetic Ingredients
}

\author{
Bok He Kang, Min Jeong Ryu \\ Department of Cosmetology Science, Graduate School of Nambu University, Gwangju, Korea
}

\author{
*Corresponding author: Min Jeong Ryu, \\ Department of Cosmetology Science, \\ Nambu University, 23 advanced Jungang- \\ ro, Gwangsan-gu, Gwangju 62271, Korea \\ Tel.: +82629700137 \\ Fax: +82629726200 \\ Email: jemine0806@hanmail.net
}

Bok He Kang and Min Jeong Ryu contributed equally to this work.

Received April 22, 2021

Revised May 17, 2021

Accepted June 02, 2021

Published June 30, 2021

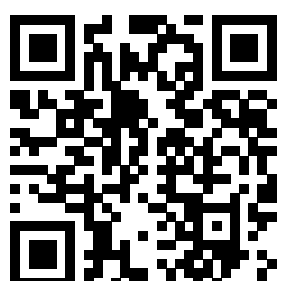

\begin{abstract}
Purpose: Recently, research and development on natural materials are actively carried out. It was conducted to confirm the applicability of Neem and Comfrey extracts as natural preservatives and cosmetic ingredients by investigating their antioxidative, antibacterial, and antifungal activities. Methods: Both Neem and Comfrey were extracted with $70 \%$ ethyl alcohol as samples, respectively. Their antibacterial and antifungal activities for antioxidative effect and against skin-related bacteria were confirmed by the Paper Disc method. Results: Both extracts were found to be highly effective in antioxidative effects, but the Comfrey extract showed higher total polyphenols and flavonoid content, stronger scavenging capability of 1,1-Diphenyl-2-picryhydrazyl (DPPH) and 2,2'-azino-bis-3-ehtylbenzothiazoline-6sulfonic acid (ABTS) radicals as well as more robust superoxide dismutase (SOD) like activities than the Neem extract did. After measuring antibacterial and antifungal effects by the Neem and the Comfrey extracts against Staphylococcus epidermidis (S. epidermidis), Staphylococcus aureus (S. aureus), Propionibacterium acnes (P. acnes), Corynebacterium xerosis (C. xerosis), Pityrosporum ovale (P. ovale), Malassezia furfur (M. furfur), Candida albicans (C. albicans), Trichophyton rubrum (T. rubrum) and Trichophyton mentagrophytes (T. mentagrophytes), which are related to the skin, it was confirmed that the Neem extract treatment showed clear zones in all 9 bacteria at $5 \mathrm{mg} / \mathrm{mL}$ concentration and particularly, 8, 7, and $7 \mathrm{~mm}$ clear zones were observed from $P$. acnes, $C$. xerosis and $T$. mentagrophytes, respectively. The Comfrey extract treatment also showed clear zones in all 9 bacteria. Especially, it showed 10, 8, 8, 10, and $11 \mathrm{~mm}$ clear zones from P. acnes, $C$. xerosis, $P$. ovale, T. rubrum and $T$. mentagrophytes. From these results, it was confirmed that the Comfrey extract had higher antibacterial and antifungal effects than the Neem extract had, and therefore, both the Neem and Comfrey extracts have excellent antibacterial effects against $P$. acnes, $C$. xerosis, and $T$. mentagrophytes among various bacteria. Conclusion: The Neem and the Comfrey extracts had great antioxidative effects as well as antibacterial and antifungal effects against 9 different skin-related bacteria. Therefore, they can be considered to be useful as natural preservatives and cosmetic ingredients.
\end{abstract}

Keywords: Neem, Comfrey, Antioxidant, Antimicrobial, Cosmetic

\section{Introduction}

피부는 신체의 가장 바깥쪽에 위치하여 표피, 진피, 피하조직으로 구성되어 있으며 다양한 환경적, 물리적, 화학적 및 생물학적인 요인 등으로부터 신체를 방어한다(Choi et al., 2019; Yang \& Jang, 2019).
외부에서 유입되는 이물질로부터 인체를 보호하고, 피지와 땀의 분비, 약물과 화장품의 흡수, 촉각, 압각, 감각의 인지 기능이 있다. 그러나 이러한 피부는 과도한 스트레스 및 환경오염으로 인하여 여드름, 색소 침착, 지루성 피부염, 아토피성 피부염, 비듬 등의 피부이상 또는 질환 이 발생한다(Kim et al., 2018). 일상생활 중에 많이 노출되는 자외선 
은 피부의 산화적 스트레스를 유발하고 노화를 가속화시킨다. 자외선에 노출된 피부에서는 활성산소종(reactive oxygen species, ROS)이 생성되 고 단백질의 산화, DNA 손상, 지질 과산화 반응을 촉진시킨다(Jeong et al., 2018). 따라서 라디칼이나 활성산소의 제거는 노화를 억제시키고 질 병을 예방할 수 있어 활성산소종을 제거하는 항산화제 개발이 다양하게 연구되고 있으며(Lim et al., 2020), 화장품 소재에서 항산화 활성은 중 요한 고려요소 중 하나로 생각된다(Kim, 2020).

피부에는 다양한 종류의 병원성, 비병원성 세균이 존재한다. 피부는 이들 세균에 대해 일차적읜 장벽으로 작용하지만, 피부에 상처가 있거나 피부장벽에 기능상 이상이 있을 경우, 이들 세균에 의한 국소적인 감염 이 발생할 수 있다(Choi et al., 2013). 그러한 균들이 피부에 미치는 영향 이 각기 다르게 나타나고, 얼굴, 두피, 외음부, 상지와 하지 등 인체의 여 러 부위의 피부에 자리 잡고 있다가, 외부자극에 지속적으로 노출이 되 면 호기성 및 혐기성균, 진균 등이 번식하게 되어 여러 가지 피부의 질병 을 유발하기도 한다(Park \& Park, 2020).

여드름 균인 $P$. ances과 비듬과 모낭염의 원인균인 $M$. furfur, $S$. aureus 균은 아토피 피부염과 밀접한 연관이 있는 것으로 알려져 있다 (Lee et al., 2018). 여드름과 같은 피부질환의 발생을 억제하기 위해 항 균제를 사용하고 있으나, 이들의 대부분은 합성물질로 피부에 allergy 등 의 부작용을 유발하고 있다. 따라서 피부 상재균에 대해 항균효과를 지 닌 천연 소재를 개발하고자 하는 연구가 활발히 진행되고 있다(Kim et al., 2017).

최근 화장품 유행성분에 대한 위험성 문제와 친환경적인 제품을 선호 하는(Kim \& Ko, 2020), 안전 지향의 소비자 경향으로 화장품 트랜드는 환경을 오염시키고 독성과 부작용을 갖는 합성원료에 비해 경쟁력이 있 는 환경 친화적 천연 성분에 대한 연구가 활발하게 진행되고 있다. 다양 한 활성을 가진 수많은 식물로부터 유용성분의 추출은 광합성 과정 중 발생되는 활성산소를 제거하기 위해 항산화 물질을 생산하고 각종 환경 오염에 저항하기 위한 다양한 활성성분을 함유하고 있어 식물의 활성성 분은 피부 노화와 만성질환을 완화하기 위해 사용되고 있다(Noh et al, 2017; Um, 2020).

님(Neem, Azadirachta indica)은 또는 nim tree라고 불리며, 멀구슬 나무과와 비슷한 종이다. 인도와 네팔, 파키스탄, 방글라데시, 스리랑 카, 몰디브와 같은 열대 및 아열대 지역에서 서식하고 높이가 12-20 m 로 급성장하는 특징을 가지고 있다. 인도 대륙에서 해충 방지제, 치과 위생, 사막화 방지 및 전통의학으로 사용되었으며(Hyun et al, 2020), azadirachtin, azadiradione, salannin, epoxyazadiradione 등의 주성분을 가지고 있다(Yoon et al., 2014a).

님 추출물의 국내 연구는 Kim et al. (2014)은 님 추출물의 Limonoid 계 살충성분 4 종의 환경매체 노출 안정성 평가를 통해 작물 지상부 병해 충 방제에 적합한 것을 판단하였다. Yoon et al. (2014b)은 님 추출물의 경구투여에 따른 랫드의 신장독성의 안정성을 확인하였다. Hyun et al, (2020)은 님트리 잎 에탄올추출물의 약리활성 및 안티폴루션 효능을 검 증하였다.
컴프리(Comfrey, Symphytum officinale)는 고단백질 함유 식물로서 각종 비타민은 물론 중요한 무기물질을 다량 함유하고 있으며 위궤양, 악성종양, 악성빈혈, 천식 등에 유효한 것으로 알려져 있다(Kang et al, 1997).

본 연구는 국내에서 잘 알려져 있지 않은 님과 컴프리 추출물의 화장 품 소재로 이용 가능성을 확인하기 위하여 항산화 효과는 총 폴리페놀과 플라보노이드 함량 측정, DPPH 와 ABTS 라디컬 소거능, $\mathrm{SOD}$ 유사활성 을 측정하였으며, 피부와 관련된 미생물에 대한 항균 및 항진균 효과를 측정함으로써 천연방부 및 화장품 소재로서 활용 가능성을 확인하고자 하였고, 유의한 결과를 얻었기에 보고하는 바이다.

\section{Methods}

\section{1. 시료 추출}

시료 추출방법은 님과 컴프리를 각각 $100 \mathrm{~g}$ 에 $70 \%$ 주정 에탄올 $1 \mathrm{~L}$ 를 가하여 $60^{\circ} \mathrm{C}$ 에서 $24 \mathrm{~h}$ 추출하고, 추출액을 여과(Whatman filter paper No.1; Whatman, UK)한 후에 회전식 감압농축기(EYELA N-1000; Tokyo Rikakikai Co, Japan)로 농축하여, 동결건조기 (PVTFA 10AT; $\mathrm{LSIN}$, Korea)에 $72 \mathrm{~h}$ 간 동결 건조하여 분말로 만들어 실험을 진행하였다.

\section{2. 남과 컴프리 추출물의 항산화 효과 측정}

\section{가. 총 폴리페놀과 플라보노이드 함량 측정}

님과 컴프리 추출물의 총 페놀 함량은 Folin \& Denis (1915) 방법에 따라 측정하였으며, 님과 컴프리 추출물 $(1 \mathrm{mg} / \mathrm{mL}) 50 \mu \mathrm{L}$ 에 증류수 $650 \mu \mathrm{L}$ 넣고 Folin-Denis' reagent $50 \mu \mathrm{L}$ 를 가하여 $3 \mathrm{~min}$ 동안 반응시 킨다. 반응시킨 후 $10 \%$ sodium carbonate $\left(\mathrm{Na}_{2} \mathrm{CO}_{3}\right.$; Sigma-Aldrich, $\mathrm{USA}$ 포화용액을 $100 \mu \mathrm{L}$ 첨가하고, 증류수 $150 \mu \mathrm{L}$ 넣어 잘 혼합시켜 $37^{\circ} \mathrm{C}$ water bath에 $1 \mathrm{~h}$ 반응시킨 후 Microplate Reader (iMARK ${ }^{\mathrm{mM}}$; Bio-Rad, USA)를 이용하여 $725 \mathrm{~nm}$ 에서 흡광도를 측정하였다. 표준 물질 tannic acid을 사용하여 표준곡선에 의해서 총 폴리페놀 함량을 구하였다.

총 플라보노이드 함량은 님과 컴프리 추출물 $(1 \mathrm{mg} / \mathrm{mL}) 100 \mu \mathrm{L}$ 에 1 $\mathrm{mL}$ diethylene glycol을 첨가하고, 다시 $1 \mathrm{~N}$ sodium hydroxide $(\mathrm{NaOH}$; Sigma-Aldrich) $100 \mu \mathrm{L}$ 넣어 잘 혼합시켜 $37^{\circ} \mathrm{C}$ water bath에 $1 \mathrm{~h}$ 반 응시킨 후 Microplate Reader Reader (iMARK ${ }^{\mathrm{TM}}$; Bio-Rad)을 이용하 여 $420 \mathrm{~nm}$ 에서 흡광도를 측정하였다. 표준물질 naringin을 사용하여 표준곡선에 의해서 총 플라보노이드 함량을 구하였다.

\section{나. DPPH 라디컬 소거능 측정}

님과 컴프리 추출물의 DPPH 라디컬 소거 효과는 Blois (1958) 방법 을 활용하여 측정하였다. 96 well plate에 $1 \mathrm{mM} \mathrm{DPPH} \mathrm{용액} 100 \mu \mathrm{L}$ 와 님과 컴프리 추출물(15.7-500 $\mu \mathrm{g} / \mathrm{mL})$ 을 $100 \mu \mathrm{L}$ 씩 취하여 혼합한 후 
실온 암실에서30 min 동안 방응시킨 후 Microplate Reader (iMARK ${ }^{\mathrm{TM}}$; $\mathrm{Bio}-\mathrm{Rad}$ )를 이용하여 $517 \mathrm{~nm}$ 파장에서 흡광도의 변화를 측정하였다. 3 회 반복실험을 실시하여 평균값을 구하였으며, 소거능은 님과 컴프리 추출물의 첨가군과 무첨가군의 흡광도 차이를 백분율로 나타내었다. 항산화 물질로 잘 알려진 ascorbic acid, BHT와 비교하였다.

\section{다. $\mathrm{ABTS}^{+}$라디컬 소거능 측정}

님과 컴프리 추출물의 $\mathrm{ABTS}^{+}$라디컬 소거능은 Re et al. (1999)의 방법으로 측정하였다. $7 \mathrm{mM}$ ABTS와 $2.45 \mathrm{mM}$ potassium persulfate 를 첨가하여 상온에서 $24 \mathrm{~h}$ 정도 방치하여 $\mathrm{ABTS}$ 용액을 준비한다. 그 다음 $\mathrm{ABTS}$ 용액 $100 \mu \mathrm{L}$ 에 님과 컴프리 추출물 $100 \mu \mathrm{L}$ 을 가한 후 암소 에서 $10 \mathrm{~min}$ 간 방치하여 후 Microplate Reader (iMARK ${ }^{\mathrm{TM}}$; $\mathrm{Bio}-\mathrm{Rad}$ ) 를 이용하여 $734 \mathrm{~nm}$ 에서 흡광도를 측정하였다. 3회 반복실험을 실시 하여 평균값을 구하였으며 음성대조군(2.45 mM potassium persulfate buffer)의 흡광도와 비교하여 흡광도를 감소시키는 정도를 백분율로 나 타내었다. 항산화 물질로 잘 알려진 ascorbic acid, BHT와 비교하였다.

\section{라. SOD 유사활성 측정}

SOD 유사활성 측정은 Marklund \& Markiund (1974)의 방법으로 실험하였다. 이 실험에서는 과산화수소와 반응을 촉매하는 pyogallol 자동산화를 측정하여 $\mathrm{SOD}$ 유사활성으로 나타냈다. Tris- $\mathrm{HCl}$ buffer (50 mM tris+10 mM EDTA, pH 8.5) $2600 \mu \mathrm{L}$ 와 $7.2 \mathrm{mM}$ pyrogallol $200 \mu \mathrm{L}$ 를 각 님과 컴프리 추출물에 $0.2 \mathrm{~mL}$ 첨가하여 $10 \mathrm{~min}$ 간 반응 시키고, $1 \mathrm{M} \mathrm{HCl} 100 \mu \mathrm{L}$ 를 가하여 반응을 정지시키고 그 중 산화된 pyrogallol의 양을 Microplate Reader (iMARK ${ }^{\mathrm{TM}}$; Bio-Rad)로 $420 \mathrm{~nm}$ 에서 흡광도를 측정하였다. $\mathrm{SOD}$ 유사활성는 시료의 용액의 첨가군고 무첨가군의 흡광도 감소율로 표시하였다.

\section{3. 님과 컴프리 추출물의 항균 및 항진균 효과}

가. 항균 및 항진균 활성에 사용된 균주 및 배양
항균활성에 사용된 미생물 균주는 한국생명공학연구원 생물자원센 터(KCTC/BRC, Korea), 한국미생물 보존센터(KCCM, Korea)에서 분 양 받았다, 실험에 사용한 각 미생물 균주, 배지 및 배양조건은 Table 1 에 정리하였다.

\section{나. Paper disc에 의한 님과 컴프리 추출물의 항균 및 항진균 활성 측정}

님과 컴프리 추출물의 항균활성은 디스크 확산법(disc diffusion assay)에 의해 측정하였다. 순수 분리된 각 균을 취해 $10 \mathrm{~mL}$ 의 액체배 지에 접종하여 각각 균의 생육적온에서 $24 \mathrm{~h}$ 씩 3회 배양 후 항균활성 시험 균으로 사용하였다. 각각의 시험 균 농도를 $650 \mathrm{~nm}$ 에서 optical density (O.D)값이 $0.4(106 \mathrm{CFU} / \mathrm{mL})$ 가 되게 한 후 $0.7 \%$ 한천이 첨가 된 배지에 잘 혼합한 다음 평판배지 위에 분주하여 균 접종 배지를 만 들었다. 멸균된 paper disk (8 mm; Advantec, Japan)를 균 접종 배지 표면에 올려놓은 후 $0.25-5 \mathrm{mg} / \mathrm{mL}$ 가 되도록 님과 컴프리 추출물을 흡수시킨 다음 $26-37^{\circ} \mathrm{C}$ 에서 $24 \mathrm{~h}$ 동안 배양 후 disc 주위의 clear zone 을 측정하였다. Clear zone은 paper disc의 직경을 포함하지 않았다. 음 성 대조군으로 $25 \%$ ethanol을 사용하였다.

\section{4. 통계처리}

본 연구의 모든 실험 결과는 3 회 이상 반복하여 평균값으로 나타내 었으며, 통계학적 유의성은 Student's $t$-test로 분석하였으며, $p$ value 가 0.05 미만일 경우 통계적으로 유의한 것으로 판정하였다 ${ }^{*} p<0.05$, $\left.{ }^{* *} p<0.01\right)$.

\section{Results and Discussion}

\section{1. 님과 컴프리 추출물의 항산화 효과}

가. 총 폴리페놀과 플라보노이드 함량 측정

님과 컴프리 추출물의 총 폴리페놀 및 플라보노이드 함량을 각각

\section{Table 1. List of strains used for experiments}

\begin{tabular}{lccc}
\hline Strains & Gram strain & Media & Temp \\
Staphylococcus epidermidis & Gram (+) & TSB & $37^{\circ} \mathrm{C}$ \\
Staphylococcus aureus & Gram (+) & TSB & $37^{\circ} \mathrm{C}$ \\
Propionibacterium acnes & Gram (+) & RCMB & $37^{\circ} \mathrm{C}$ \\
Corynebacterium xerosis & Gram (-) & BHIB & $37^{\circ} \mathrm{C}$ \\
Pityrosporum ovale & Yeast & YMB & $37^{\circ} \mathrm{C}$ \\
Malassezia furfur & Yeast & YMB & $30^{\circ} \mathrm{C}$ \\
Candida albicans & Yeast & LBB & $37^{\circ} \mathrm{C}$ \\
Trichophyton rubrum & Fungi & SDB & $26^{\circ} \mathrm{C}$ \\
Trichophyton mentagrophytes & Fungi & SDB & $26{ }^{\circ} \mathrm{C}$ \\
\hline
\end{tabular}

TSB, trypticase soy broth; RCMB, reinforced clostridial medium broth; BHBI, brain heart infusion broth; YMB, yeast medium broth; LBB, luria bertani broth; SDB, saboraud dextrose broth. 
tannic acid, naringin을 기준 물질로 하여 측정하였다. 폴리페놀 화 합물이 phosphomolybdate와 반응하여 노란색에서 청색으로 변색되 는 원리로 식물 추출물 내의 폴리페놀은 항산하 활성 또는 생리활성 에 기여하는 것으로 알려져 있다(Park \& Lee, 2020)

님과 컴프리 추출물 $1 \mathrm{mg} / \mathrm{mL}$ 농도에서 총 폴리페놀 함량 은 tannic acid 표준 곡선으로 하여 측정한 결과, $149.27 \pm 2.32$, $235.82 \pm 2.75 \mu \mathrm{g} / \mathrm{mL}$ 으로 나타났다(Table 2).

플라노보이드는 식물계에 분포하는 이차 대산물로 구조적으로 phenolic hydroxyl기가 존재하여 free radical 소거활성이 우수하고 자외선에 대한 필터작용, 활성산소 제거를 통한 항산화 작용을 하는 것으로 알려져 있다(Choi \& Moon, 2017).

Naringin을 표준 곡선으로 총 플라보노이드 함량을 측정한 결과 님과 컴프리 추출물 $1 \mathrm{mg} / \mathrm{mL}$ 농도에서 $50.75 \pm 1.53,60.17 \pm 2.45$ $\mu \mathrm{g} / \mathrm{mL}$ 로 나타났다(Table 2).

\section{나. $\mathrm{DPPH}$ 라디컬 소거능 측정}

체내에 발생하는 free radical은 매우 불안정하여 무차별적으로 반 응할 뿐만 아니라, 이러한 산화반응은 각종 질병을 유발하며, 특히 피 부 노화를 촉진시킨다. 따라서 free radical을 안정화시키면 간접적으 로 피부의 노화를 예방한다고 말할 수 있다(Lee et al., 2016). 님과 컴 프리 추출물의 DPPH radical 소거능을 측정한 결과(Figure 1), 15.7-

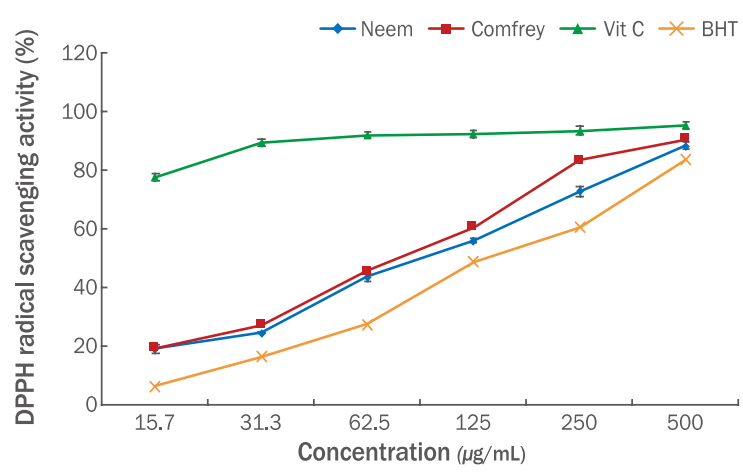

Figure 1. DPPH radical scavenging activities of neem and comfrey extracts.

DPPH radical scavenging assays were conducted to investigate neem and comfrey antioxidant effects in ethanol extracts at varying concentrations of $15.7,31.3,62.5,125,250$, and $500 \mu \mathrm{g} / \mathrm{mL}$, respectively. Vit C, ascorbic acid; BHT, butylated hydroxytoluene group; DPPH, 1,1-diphenyl-2-picrylhydrazyl.

$500 \mu \mathrm{g} / \mathrm{mL}$ 농도에서, 님 추출물은 $18.8,24.43,43.36,55.78$, $72.66,88.12 \%$ 의 소거능이 확인 되었으며, 컴프리 추출물은 19.12 , $27.09,45.41,60.34,83.07,90.14 \%$ 의 소거능이 확인 되었다. 양

Table 2. Total phenolic and flavonoid contents of neem and comfrey extracts

\begin{tabular}{lcc}
\hline Components & Neem & Comfrey \\
Total phenolic & $149.27 \pm 2.32$ & $235.82 \pm 2.75$ \\
Total flavonoids & $50.75 \pm 1.53$ & $60.17 \pm 2.45$ \\
\hline
\end{tabular}

Values represent the $\mathrm{M} \pm \mathrm{S}$.D. of three independent experiments.

Table 3. Antimicrobial activity of neem and comfrey extracts

\begin{tabular}{|c|c|c|c|c|c|c|c|c|c|}
\hline \multirow{3}{*}{ Bacteria } & \multicolumn{9}{|c|}{ Inhibition zone diameter $(\mathrm{mm})$} \\
\hline & \multicolumn{2}{|c|}{$5(\mathrm{mg} / \mathrm{mL})$} & \multicolumn{2}{|c|}{$1(\mathrm{mg} / \mathrm{mL})$} & \multicolumn{2}{|c|}{$0.5(\mathrm{mg} / \mathrm{mL})$} & \multicolumn{2}{|c|}{$0.25(\mathrm{mg} / \mathrm{mL})$} & \multirow{2}{*}{$\begin{array}{l}\text { Control } \\
\text { Ethano }\end{array}$} \\
\hline & Neem & Comfrey & Neem & Comfrey & Neem & Comfrey & Neem & Comfrey & \\
\hline S. epidermidis & 4 & 5 & 2 & 3 & 1 & 2 & 1 & 1 & $-1)$ \\
\hline S. aureus & 4 & 6 & 2 & 3 & 1 & 1 & 1 & 1 & - \\
\hline P. acnes & 8 & 10 & 4 & 6 & 2 & 3 & 1 & 1 & - \\
\hline C. xerosis & 7 & 8 & 3 & 6 & 2 & 2 & 1 & 1 & \\
\hline P. ovale & 5 & 8 & 3 & 6 & 2 & 4 & 1 & 2 & - \\
\hline M. furfur & 4 & 6 & 3 & 3 & 2 & 2 & 1 & 2 & - \\
\hline C. albicans & 4 & 6 & 3 & 3 & 2 & 2 & 1 & 1 & - \\
\hline T. rubrum & 6 & 10 & 3 & 7 & 2 & 4 & 1 & 2 & \\
\hline T. mentagrophytes & 7 & 11 & 4 & 8 & 3 & 6 & 1 & 3 & - \\
\hline
\end{tabular}

\footnotetext{
${ }^{1)}$ No inhibition; EE, 70\% ethanol extract; WE, water extract. S. epidermidis, Staphylococcus epidermidis; S. aureus, Staphylococcus aureus; P. acnes, Propionibacterium acnes; E. coli, Escherichia coli; P. ovale, Pityrosporum ovale; M. furfur, Malassezia furfur, C. albicans, Candida albicans; T. rubrum, Trichophyton rubrum; T. mentagrophytes, Trichophyton mentagrophytes.
} 


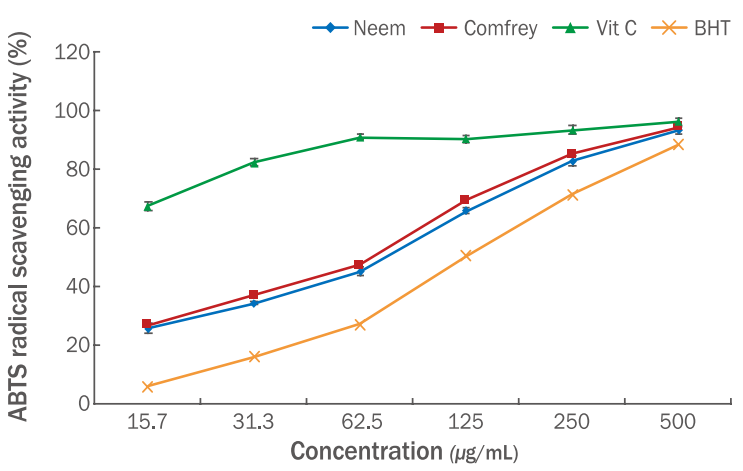

Figure 2. ABTS radical scavenging activities of neem and comfrey extracts.

ABTS radical scavenging assays were conducted to investigate neem and comfrey antioxidant effects in ethanol extracts at varying concentrations of $15.7,31.3,62.5,125,250$, and $500 \mu \mathrm{g} / \mathrm{mL}$, respectively. Vit C, ascorbic acid; BHT, butylated hydroxytoluene group; ABTS, 2.2'-azino-bis-3-ehtylbenzothiazolin-6sulfonic acid.

성 대조군으로 사용된 vitamin $\mathrm{C}$ 는 $77.41,89.24,91.82,92.19$, $93.13,95.25 \%$ 의 소거능이 확인되었고, BHT의 경우 $6.08,16.32$, $27.36,48.49,60.31,84.38 \%$ 의 소거능이 확인되었다.

\section{다. $\mathrm{ABTS}^{+}$라디컬 소거능 측정}

$\mathrm{ABTS}^{+}$라디컬 소거능은 $\mathrm{ABTS}$ 와 potassium sulfate의 산화에 의 해 생성된 $\mathrm{ABTS}^{+}$라디컬이 항산화 물질에 의해 청록색에서 무색으 로 탈색되는 항산화 활성 측정법이다(Yang \& Lee, 2019). 님과 컴프 리 추출물의 $\mathrm{ABTS}^{+}$라디컬 소거능을 측정한 결과(Figure 2), 15.7$500 \mu \mathrm{g} / \mathrm{mL}$ 농도에서 님 추출물은 $28.8,34,43,45.21,65.78$, $82.66,93.12 \%$ 의 소거능이, 컴프리 추출물은 $27.12,37.09,47.41$, $69.34,85.07,94.14 \%$ 의 소거능이 확인되었다. 양성 대조군으로 사 용된 vitamin C는 67.41, 82.24, 90.82, 90.19, 93.13\%, 96.15\% 소거능이 확인되었고, BHT의 경우 $6.08,16.32,27.36,50.49$, $71.31,88.38 \%$ 의 소거능이 확인되었다.

\section{라. SOD 유사활성 측정}

자유 라디컬을 근본적으로 제거하는 항산화 효소의 하나인 SOD 는 세포에 해로운 환원 산소종을 과산화수로로 전환 시키는 반응을 촉매하는 효소로 $\mathrm{SOD}$ 에 의해 생성된 $\mathrm{H}_{2} \mathrm{O}_{2}$ 는 peroxidase나 catalase 에 의하여 무해한 물분자와 산소분자로 전환시켜 외부에 침입하는 세균 등에 대한 방어와 신호전달효과로 생체를 보호하는 역할을 한 다(Lee et al, 2013). 피부 노화방지와 밀접한 관련이 있는 SOD 유 사활성능은 superoxide와 반응하여 갈변물질을 내는 pyrogallol의 자동 산화반응을 측정한 결과를 Figure 3에 나타내었다. 15.7-500 $\mu \mathrm{g} / \mathrm{mL}$ 농도에서 님 추출물은 $8.16,19.52,32.15,49.27,55.21$,

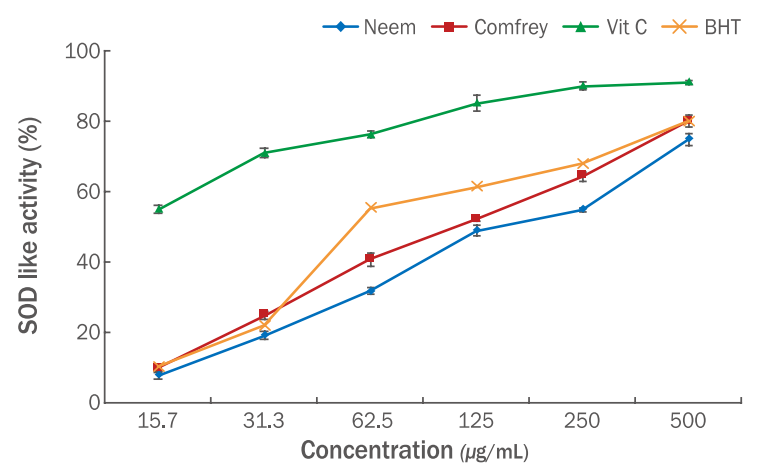

Figure 3. SOD like activities of neem and comfrey extracts. SOD like activity assays were conducted to investigate neem and comfrey antioxidant effects in ethanol extracts at varying concentrations of $15.7,31.3,62.5,125,250$, and $500 \mu \mathrm{g} / \mathrm{mL}$, respectively. Vit $\mathrm{C}$, ascorbic acid; $\mathrm{BHT}$, butylated hydroxytoluene group.

$75.12 \%$ 의 유사활성능이 확인되었으며, 컴프리 추출물은 10.27 , $25.16,41.14,52.42,64.53,80.24 \%$ 의 유사활성능이 확인되었다. 양성 대조군으로 사용된 vitamin C는 55.17, 71.21, 76,43, 85.32, $90.21,91.24 \%$ 의 유사활성능이 확인되었고, BHT의 경우 10.71 , $22.31,55.52,61.49,68.13,80.15 \%$ 로 확인되었다.

\section{2. 님과 컴프리 추출물의 항균 및 항진균 활성}

피부 관련 균에 대한 님과 컴프리 추출물의 항균 및 항진균 활성 을 측정하기 위해 디스크 확산법(disc diffusion assay)에 의해 clear zone을 확인하였다. 그 결과, 님과 컴프리 추출물은 9 개 균에서 항균 력이 모두 확인되었다(Table 3, Figure 4).

S. epidermidis는 외모낭이나 모낭 중간에 성장하며 원발성 피 부질환 및 아토피 피부염에 요인이 되어 피부 모공 또는 상처에 화 농을 유발 시키며 악화시키는 원인이 된다(Kim et al., 2019). S. epidermidis에 대한 항균효과를 측정한 결과 님 추출물은 $5,1 \mathrm{mg} /$ $\mathrm{mL}$ 농도에서 $4,1 \mathrm{~mm}$ 의 clear zone이 확인되었으며, 컴프리 추출 물은 $5,1,0.5 \mathrm{mg} / \mathrm{mL}$ 의 농도에서 $4,2,1 \mathrm{~mm}$ 의 clear zone이 확 인되었다.

S. aureus는 피부나 환경 중에 존재하고 있는 병원성 세균으로 주 로 염증을 통해서 고름형성, 피부발진 등의 증상으로 감염을 나타난 다(Yang \& Jang, 2019). S. aureus에 대한 항균효과를 측정한 결과 님 추출물은 $5,1 \mathrm{mg} / \mathrm{mL}$ 농도에서 $4,1 \mathrm{~mm}$ 의 clear zone이 확인되 었으며, 컴프리 추추출물은 $5,1,0.5 \mathrm{mg} / \mathrm{mL}$ 의 농도에서 농도에서 $6,3,1 \mathrm{~mm}$ 의 clear zone이 확인되었다.

여드름은 모낭-피지선에서 발생하는 피부질환으로 피지선에서 피지 분비가 증가하거나 피지선의 모공이 좁아지든지 막혀서 피지가 배출되지 못함에 따라 세균이 증식하여 염증이 생기는 것이다(Jo et al., 2020). 여드름의 원인균인 P. acnes에 대한 항균효과를 측정한 


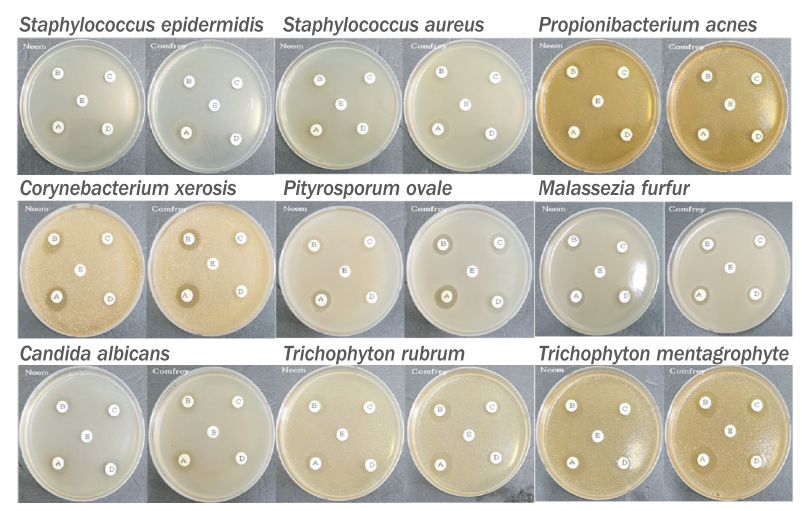

Figure 4. Antimicrobial activity of neem and comfrey extracts on Staphylococcus epidermidis, Staphylococcus aureus, Propionibacterium acnes, Corynebacterium xerosis, Pityrosporum ovale, Malassezia furfur, Candida albicans, Trichophyton rubrum, Trichophyton mentagrophyte.

A, $5 \mathrm{mg} / \mathrm{mL}$; B , $1 \mathrm{mg} / \mathrm{mL}$; C, $0.5 \mathrm{mg} / \mathrm{mL}$; D, $0.25 \mathrm{mg} / \mathrm{mL}$; , control.

결과, 님 추출물은 $5,1,0.5,0.25 \mathrm{mg} / \mathrm{mL}$ 의 농도에서 각각 $8,6,3$, $2 \mathrm{~mm}$ 의 clear zone이 확인되었으며, 컴프리 추출물은 각각 10,7 , $3,2 \mathrm{~mm}$ 의 clear zone이 확인되었다.

액취는 아포크린 한선질환으로 피부에서 악취가 나는 악취성 발 한이며, 주로 액와에서 발생된다. 액취의 특유한 냄새는 겨드랑이 등 특정부위에 분포되어 있는 아포크린 한선에 있는 세균의 일종인 피 부상재균에 의해 분해되거나 또는 자가 산화되어 불쾌한 냄새의 지 방산을 생산하기 때문에 발생한다(Roh et al., 2009). C. xerosis에 대한 항균효과를 측정한 결과, 님 추출물은 $7,4,1,1 \mathrm{~mm}$ 의 clear zone이 확인되었으며, 컴프리 추출물은 각각 $8,6,2,1 \mathrm{~mm}$ 의 clear zone이 확인되었다.

비듬이란 두피의 노화 각편이 쌀겨 모양으로 탈락하는 것과 피지 의 분해 산화물이 혼합된 상태로 살아있는 피부 세포에서 자연스럽 게 생겨나게 되는 신진대사의 부산물이며 경미한 지루성 피부염이라 고 할 수 있다. 두피가 심한 통증이나 가려움증 또는 염증이나 홍반 을 동반하는 경우에는 비듬균이 원인이 되어 나타나는 증상들로 반 드시 비듬균의 성장을 억제해야 한다(Lee et al., 2013). P. ovale에 대한 항균효과를 측정한 결과, 님 추출물은 $5,1,0.5 \mathrm{mg} / \mathrm{mL}$ 의 농 도에서 $5,3,1 \mathrm{~mm}$ 의 clear zone이 확인되었으며, 컴프리 추출물 은 $5,1,0.5,0.25 \mathrm{mg} / \mathrm{mL}$ 의 농도에서 각각 $8,6,4,3 \mathrm{~mm}$ 의 clear zone이 확인되었다. M. furfur에 대한 항균효과를 측정한 결과 님 추출물은 각각 $5,3,2,2 \mathrm{~mm}$ 의 clear zone이 확인되었으며, 컴프리 추출물은 각각 $5,3,2,2 \mathrm{~mm}$ 의 clear zone이 확인되었다.

피부질환을 유발하는 대표적인 균류는 $C$. albicans로서, 기저귀를 하는 갓난아기의 피부염과 여성의 질염을 유발한다(Chung \& Kim, 2019). C. albicans에 대한 항진균효과를 측정한 결과 님 추출물은 각각 $4,2,1,1 \mathrm{~mm}$ 의 clear zone이 확인되었으며, 컴프리 추출물은 $6,3,1,1 \mathrm{~mm}$ 의 clear zone이 확인되었다.

진균들은 백선(ringworm), 두부백선, 서혜부 백선 및 무좀 (ahhlet's foot), 손톱, 발콥 등 전형적인 피부 감염을 일으킨다(Kim \& Lee, 2013). 무좀은 백선균이 원인으로 생기는 피부병으로 고온 다습한 여름철에 주로 손과 발에 발생하였으나 생활환경, 직업, 면 역상태 및 무좀균의 종류 등에 따라 신체의 어느 부위에나 발생이 가 능하다(Lee, 2003). 표재성 진균증을 일으키는 원인균 T. rubrum에 대한 항진균 효과를 측정한 결과 님 추출물은 $6,3,2,1 \mathrm{~mm}$ 의 clear

Table 3. Antimicrobial activity of neem and comfrey extracts.

\begin{tabular}{|c|c|c|c|c|c|c|c|c|c|}
\hline \multirow{3}{*}{ Bacteria } & \multicolumn{9}{|c|}{ Inhibition zone diameter (mm) } \\
\hline & \multicolumn{2}{|c|}{$5(\mathrm{mg} / \mathrm{mL})$} & \multicolumn{2}{|c|}{$1(\mathrm{mg} / \mathrm{mL})$} & \multicolumn{2}{|c|}{$0.5(\mathrm{mg} / \mathrm{mL})$} & \multicolumn{2}{|c|}{$0.25(\mathrm{mg} / \mathrm{mL})$} & \multirow{2}{*}{$\begin{array}{l}\text { Control } \\
\text { Ethano }\end{array}$} \\
\hline & Neem & Comfrey & Neem & Comfrey & Neem & Comfrey & Neem & Comfrey & \\
\hline S. epidermidis & 4 & 5 & 2 & 3 & 1 & 2 & 1 & 1 & $-1)$ \\
\hline S. aureus & 4 & 6 & 2 & 3 & 1 & 1 & 1 & 1 & - \\
\hline P. acnes & 8 & 10 & 4 & 6 & 2 & 3 & 1 & 1 & - \\
\hline C. xerosis & 7 & 8 & 3 & 6 & 2 & 2 & 1 & 1 & \\
\hline P. ovale & 5 & 8 & 3 & 6 & 2 & 4 & 1 & 2 & - \\
\hline M. furfur & 4 & 6 & 3 & 3 & 2 & 2 & 1 & 2 & - \\
\hline C. albicans & 4 & 6 & 3 & 3 & 2 & 2 & 1 & 1 & - \\
\hline T. rubrum & 6 & 10 & 3 & 7 & 2 & 4 & 1 & 2 & \\
\hline T. mentagrophytes & 7 & 11 & 4 & 8 & 3 & 6 & 1 & 3 & - \\
\hline
\end{tabular}

\footnotetext{
1) No inhibition. EE, 70\% ethanol extract; WE, water extract. S. epidermidis, Staphylococcus epidermidis; S. aureus, Staphylococcus aureus; P. acnes, Propionibacterium acnes; E. coli, Escherichia coli; P. ovale, Pityrosporum ovale; M. furfur, Malassezia furfur; C. albicans, Candida albicans; T. rubrum, Trichophyton rubrum; T. mentagrophytes, Trichophyton mentagrophytes.
} 
zone이 확인되었으며, 컴프리 추출물은 $10,8,4,3 \mathrm{~mm}$ 의 clear zone이 확인되었다. T. mentagrophytes에 대한 항진균 효과를 측정 한 결과 님 추출물은 $8,6,3,1 \mathrm{~mm}$ 의 clear zone이 확인되었으며, 컴프리 추출물은 $11,8,4,3 \mathrm{~mm}$ 의 clear zone이 확인되었다.

\section{Conclusion}

본 연구는 천연소재에 대한 연구·개발이 활발히 이루어지고 있는 상황에 님과 컴프리 추출물의 항산화, 항균 및 항진균 효능을 확인함 으로써 천연방부 및 화장품 소재로 활용 가능성을 확인하기 위하여 수행하였다.

님과 컴프리 추출물의 항산화 활성을 확인한 결과는 총 폴리페놀 함량은 $1 \mathrm{mg} / \mathrm{mL}$ 농도에서 각각, $149.27 \pm 2.32,235.82 \pm 2.75 \mu \mathrm{g} /$ $\mathrm{mL}$ 으로 나타났으며, 총 플라보노이드 함량은 $50.75 \pm 1.53,60.17$ $\pm 2.45 \mu \mathrm{g} / \mathrm{mL}$ 로 나타났다. $\mathrm{DPPH}$ 와 $\mathrm{ABTS}$ 소거능에서 님 추출물 은 $500 \mu \mathrm{g} / \mathrm{mL}$ 농도에서 각각 $88.15 \%, 93.12 \%$ 소거능이 확인 되었 으며, 컴프리 추출물은 각각 $90.18 \%, 94.14 \%$ 의 소거능이 확인 되었 다. 컴프리 추출물은 님 추출물 보다 항산화 효과가 높게 확인 되었 다.

님과 컴프리 추출물의 피부와 관련된 $S$. epidermidis, $S$. aureus, $P$. acnes, $C$. xerosis, $P$. ovale, $M$. furfur, $C$. albicans, $T$. rubrum, T. mentagrophytes에 대한 항균 및 항진균 효과를 측정한 결과 $5 \mathrm{mg} / \mathrm{mL}$ 농도에서 님 추출물은 9 개 균 모두에서 clear zone을 관찰할 수 있었고, 특히 P. acnes, C. xerosis, T. mentagrophytes 에서 각각 $8,7,7 \mathrm{~mm}$ clear zone을 확인할 수 있었다. 컴프리 추 출물도 9 개 균 모두에서 clear zone을 관찰할 수 있었고, 특히 $P$. acnes, C. xerosis, P. ovale, T. rubrum, T. mentagrophytes에서 각각 $10,8,8,10,11 \mathrm{~mm}$ 의 clear zone을 확인할 수 있었다. 이러 한 결과 컴프리 추출물이 님 추출물에 비해 항균 및 항진균 효과가 더 높게 확인 되었으며, 미생물에 따라서 님과 컴프리 추출물 모두 P. acnes, C. xerosis, T. mentagrophytes에 대한 항균력이 우수함 을 보여준다.

이상의 연구 결과로부터 님과 컴프리 추출물은 항산화 효과가 우 수하였으며, 피부와 관련 9 개의 균에 대한 항균 및 항진균 효과가 우 수함이 확인 되어 천연방부 및 화장품 원료로 유용하게 사용될 수 있 을 것으로 사료된다.

\section{Author's contribution}

BHK and MJR contributed equally to this work. BHK and MJR designed all experimental investigations and developed a process to check the possibilities with cosmetic materials. BHK designed and supported the experiment, participated in the experiment, and MJR wrote the manuscript with the help of BHK.

\section{Author details}

Bok He Kang (Graduate student), Department of Cosmetology Science, Nambu University, 23 advanced Jungang-ro, Gwangsan-gu, Gwangju 62271, Korea; Min Jeong Ryu (Professor), Department of Cosmetology Science, Nambu University, 23 advanced Jungang-ro, Gwangsangu, Gwangju 62271, Korea.

\section{References}

Blois MS. Antioxidant determinations by the use of a stable free radical. Nature, 181: 1199-1200, 1958.

Choi JE, Moon JS. Physiological activities of parsley extracts as an ingredient of functional cosmetics. Asian Journal of Beauty and Cosmetology, 15: 501-511, 2017.

Choi SI, Lee JS, Cho BY, Choi SH, Sim SW, Han XH, Jang GW, Kwon HY, Choi YE, Kim JD, et al. Antioxidant and anti-aging effects of extracts from leaves of Chamaecrista nomame (Siebold) H. Ohashi on oxidative stress-induced human dermal fibroblasts. Journal of the Korean Society of Food Science and Nutrition, 48: 933-942, 2019.

Choi SH, Kim HJ, Lee BC, Moon TK, Kim NS. Clinical evaluation of residual effectiveness of antibacterial agents. Journal of the Society of Cosmetic Scientists of Korea, 39: 133-140, 2013.

Chung KT, Kim BW. Anti-microbial activity effects of ozonized olive oil against bacteria and Candida albicans. Journal of Life Science, 22: 223-230, 2019.

Folin O, Denis W. A colorimetric method for the determination of phenols (and phenol derivatives) in urine. Journal of Biological Chemistry, 22: 305-308, 1915.

Hyun JA, Lee JH, Kang EB, Kim HJ, Kim DI, Park GE, Kwak KS, An BJ. Validation of pharmacological activity and antipollution effect of ethanol extract of Azadirachta indica leaf. Korean Journal of Food Preservation, 27: 393-406, 2020.

Jeong HJ, Xuan SH, song BR, Lee SL, Lee YJ, Park SN. Antimicrobial and antioxidant activities of Perilla frutescens var. acuta extract and its fraction and their component analyses. Applied Chemistry for Engineering, 29: 716-725, 2018. 
Jo SM, Kim JE, Lee NH. Anti-inflammatory and anti-bacterial active ingredients derived from the extract of the leaves of Hydrangea petiolaris. Journal of the Society of Cosmetic Scientists of Korea, 46: 23-29, 2020.

Kang IJ, Ham SS, Chung CK, Lee SY, Oh DH, Choi KP, Do JJ. Development of fermented soysauce using Cirsium setidens Nakai and comfrey. Archives of Soybean Fermentation Foods Research, 26: 1152-1158, 1997.

Kim JE, Jo SM, Lee NH. Anti-oxidative and anti-bacterial constituents from the extracts of Rhododendron weyrichii leaves. Journal of the Society of Cosmetic Scientists of Korea, 45: 341-351, 2019.

Kim JE, Jo YJ, Lee NH. Anti-inflammatory and anti-bacterial constituents from the extracts of Daucus carota var. sativa Aerial parts. Journal of the Society of Cosmetic Scientists of Korea, 44: 427-436, 2018.

Kim JH, Jeong DY, Jin CL, Kim WI, LimSJ, Choi GH, Park BJ. Stability of four limonoidal substance of neem extract under controlled aquatic and soil conditions. The Korean Journal of Pesticide Science, 18: 156-160, 2014.

Kim HS, Ko KS. Antioxidant and anti-inflammatory effects of ginseng berry ethanol extracts as a cosmetic ingredient. Asian Journal of Beauty and Cosmetology, 18: 389-397, 2020.

Kim HO. Anti-oxidant and moisturizing effects of oil extracted from Tenebrio molitor Larvae. Asian Journal of Beauty and Cosmetology, 18: 273-281, 2020.

Kim YB, Lee HH. Naturopathic effects of wood vinegar treatments to the superficial mycosis. Journal of Naturopathy, 2: 1-11, 2013.

Kim YD, Kim YM, Mo EK. Antibacterial, antioxidant, and antiaging effects of the ethanol extract of Dolnamul (Sedum sarmentosum) and the production of the oil in water cream. Journal of the Society of Cosmetic Scientists of Korea, 43: 211-221, 2017.

Lee JR, Jung DH, Park MK. Antifungal activities of hemistepsin $A$ and $B$ isolated from Hemistepita lyrata bunge against Dandruff-causing microbe Malassezia obutusa. Korean Society for Biotechnology and Bioengineering Journal, 28: 74-79, 2013.

Lee AR, Roh SS, Kim HK. Anti-microbial activity and antiinflammatory effects of fucoidan extracts. Asian Journal of Beauty and Cosmetology, 16: 191-200, 2018.

Lee AR, Roh SS, Sook LE, Min YH. Anti-oxidant and anti- melanogenic activity of the methanol extract of pine cone. Asian Journal of Beauty and Cosmetology, 14: 301-308, 2016.

Lee JM, Kim LC, Hur SS. Studies on cosmeceutical activity of extracts of persimmon leaves. Journal of Investigative Cosmetology, 9: 371-378, 2013.

Lee SK. Antimicrobial effect of Bamboo (Phyllosrachys Bambusoides) essential oil on trichophyton and pityrosporum. Journal of Food Hygiene and Safety, 18: 113-117, 2003.

Lim JM, Lee JS, Lee JH. Analysis of Zanthoxylum schinifolium for use in natural cosmetic material development. Journal of Investigative Cosmetology, 16: 183-196, 2020.

Marklund S, Marklund G. Involvement of the superoxide anion radical in the autoxidantion of pyrogallol and a convenient assay for superoxide dismutase. European Journal of Biochemistry, 47: 469-474, 1974.

Noh JS, Park SY, Jeong KS. Extraction characteristics and antioxidant activity of ethanol extract of Rhus javanica Bark. Journal of Oil \& Applied Science, 34: 555-561, 2017.

Park GH, Park JY. Screening of the antibacterial, antifungal and antioxidative activities of a bamboo-distilled extract for use in cosmetics. Journal of Investigative Cosmetology, 16: 239-247, 2020.

Park GR, Lee JA. Anti-oxidant, anti-inflammatory and whitening effect of Benincasa hipoda seed extract. Journal of Convergence for Information Technology, 10: 249-256, 2020.

Re R, Pellegrini N, Pannala A, Yang M, Rice-Evans C. Antioxidant activity applying an improved ABTS radical cation decolorization assay. Free Radical Biology and Medicine, 26: 1231-1237, 1999.

Roh SS, Yun WS, Jung JY, Yu HU, Hwang DS, Choi SM, Lee JR, Kang SJ. The effect of body wash containing triclosan and bamboo salt on axillary malodor. Journal of the Society of Cosmetic Scientists of Korea, 35: 219-228, 2009.

Um MS. The evaluation on the effectiveness of Zingiber mioga extract as a cosmetic material through verification of cosmeceutical activations. Journal of the Korean Applied Science and Technology, 37: 1088-1099, 2020.

Yang JC, Jang DY. Evaluation of anti-oxidative and antimicrobial activity of Rhus javanica L fruit extract. Culture and Convergence, 41: 847-870, 2019.

Yang Y, Lee JA. Antioxidant and anti-inflammatory effect of Pyracantha angustifolia fruit extracts. Journal of 
Convergence for Information Technology, 9: 294-301, 2019.

Yoon HJ, Cho HJ, Kim JH, Park KH, Gil GH, Oh JA, Cho JN, Pail MK. In vitro antimutagenic and genotoxic effects of Azadirachta indica extract. Journal of Applied Biological Chemistry, 57: 219-225, 2014a.
Yoon HJ, Choe MS, Cho HJ, Han BS, Park KH, Oh JA, Cho NJ, Pail MK. Study of kidney toxicity of Azadirachta indica extract for oral administration in rats. Korean Journal of Environmental Agriculture, 33: 103-110, $2014 b$. 


\section{국문초록}

\section{님과 컴프리 추출물의 화장품 소재로써 생리활성 연구}

강복희, 유민정*

남부대학교 향장미용학과, 광주, 한국

목적: 천연소재에 대한 연구개발이 활발히 이루어지고 있는 상황에 님과 컴프리 추출물의 항산화, 항균 및 항진균 효능을 확인함 으로써 천연방부 및 화장품 원료로 활용 가능성을 확인하기 위하여 수행하였다. 방법: 님과 컴프리를 각각 $70 \%$ 주정에탄올로 추출 하여 시료로 사용하였다. 항산화 효과 및 피부관련 균에 대해 paper disc법을 사용하여 항균 및 항진균 효과를 확인 하였다. 결과: 님과 컴프리 추출물의 항산화 효과에서는 님과 컴프리 추출물 모두 효과가 높게 확인되었지만 그 중에서 컴프리 추출물이 님 추출 물 보다 총 폴리페놀과 플라보노이드 함량, $\mathrm{DPPH}$ 와 $\mathrm{ABTS}$ 라디컬 소거능이 높게 확인되었으며, $\mathrm{SOD}$ 유사활성도 컴프리 추출물 이 높게 확인 되었다. 님과 컴프리 추출물의 피부와 관련된 $S$. epidermidis, $S$. aureus, $P$. acnes, C. xerosis, P. ovale, M. furfur, C. albicans, T. rubrum, T. mentagrophytes에 대한 항균 및 항진균 효과를 측정한 결과 $5 \mathrm{mg} / \mathrm{mL}$ 농도에서 님 추출물은 9 개 균 모두에서 clear zone을 관찰할 수 있었고, 특히 P. acnes, C. xerosis, T. mentagrophytes에서 각각 8, 7, $7 \mathrm{~mm}$ clear zone 확인할 수 있었다. 컴프리 추출물도 9 개 균 모두에서 clear zone을 관찰할 수 있었고, 특히 P. acnes, C. xerosis, P. ovale, T. rubrum, T. mentagrophytes에서 각각 $10,8,8.10,11 \mathrm{~mm}$ 의 clear zone을 확인할 수 있었다. 이러한 결과 컴프리 추출물이 님 추출물에 비해 항균 및 항진균 효과가 더 높게 확인 되었으며, 미생물에 따라서 님과 컴프리 추출물 모두 P. acnes, C. xerosis, T. mentagrophytes 에 대한 항균력이 우수함을 보여준다. 결론: 님과 컴프리 추출물은 항산화 효과가 우수하였으며 피부와 관련 9 개의 균에 대한 항균 및 항진균 효과가 우수함이 확인 되어 천연방부 및 화장품 원료로 유용하게 사용될 수 있을 것으로 사료된다.

핵심어: 님, 컴프리, 항산화효과, 항균효과, 화장품

\section{참고문헌}

강일준, 함승시, 정차권, 이상영, 오덕환, 최근표, 도재준. 고려엉겅퀴 및 컴프리를 이용한 양조간장의 개발. 한국식품영양 과학회지. 26: $1152-1158,1997$.

김정은, 조성미, 이남호. 참꽃나무 잎 추출물 유래 항산화 및 항균 활성 성분. 대한화장품학회지, 45: 341-351. 2019. 김정은, 조연정, 이남호. 당근 지상부 추출물 유래 항염 및 항균 활성 성분. 대한화장품학회지, 44: 427-436, 2018.

김진효, 정두연, 진초롱, 김원일, 임성진, 최근형, 박병준. 님나무 추출물의 Limpnoid계 살충성분 4 종의 환경매체 노출 안 정성. 농약학회지. 18: 156-160, 2014.

김영대, 김영민, 모은경. 돌나물(Sedum sarmentosum) 에탄올 추출물의 항균, 항산화, 항노화 효과와 수중유적형 크림의

제조. 대한화장품학회지, 43: 211-221, 2017.

김유복, 이형환. 목초액의 표재성진균증 임상치유 효과. 한국자연치유학회지, 2: 1-11, 2013.

김현숙, 고경숙. 인삼열매 에탄올 추출물의 화장품 소재로서 항산화, 항염효과. 아시안뷰티화장품학술지, 18: 389-397, 2020.

김혜옥. 갈색거저리 유층 오일의 항산화 및 보습활성. 아시안뷰티화장품학술지, 18: 273-281, 2020.

노석선, 윤우식, 정지영, 유형욱, 황동성, 최승만, 이정래, 강상진, 장석윤. Triclosan과 죽염을 함유한 바디워시의 액취 등

에 미치는 효과에 대한 연구. 대한화장품학회지, 35: 219-228, 2009.

노정숙, 박선이, 정갑섭. 붉나무 껍질 에탄올 추출물의 추출특성과 항산화 활성에 관한 연구. 한국유화학회지, $34: 555-$

$561,2017$.

박규리, 이지안. 동과자 추출물의 항산화, 항염 및 미백 효능. 융합정보논문지, 10: 249-256, 2020. 
박가희, 박정연. 화장품 소재 탐색을 위한 대나무 증류 추출물의 항균, 항진균 및 항산화 효과. 대한미용학회지, 16: 239$247,2020$.

이숙경. 무좀균과 비듬균에 대한 대나무 기름의 항균효과. 한국식품위생안전성학회지, 18: 113-117, 2003.

이아름, 노성수, 김현정. 후코이단 추출물의 항균 및 항산화 효과. 아시안뷰티화장품학술지, 16: 191-200, 2018.

이아름, 노성수, 이은숙, 민유홍. 솔방울 메탄올 추출물의 항산화 및 멜라닌 생성 억제효과. 아시안뷰티화장품학술지, 14 : 301-308, 2016.

이진만, 김일출, 허상선. 감나무(Diospyros kaki Thunb) 잎 추출물에 대한 화장품 약리활성 검증. 대한미용학회지, 9 : 371-378, 2013.

임정묵, 이종순, 이정호. 천연화장품 소재 개발을 위한 산초 성분분석 및 생리활성 평가. 대한미용학회지, 16: 183-196, 2020.

이종록, 정대화, 박문기. 지챙개에서 분리한 Hemistepsin A와B의 비듬균에 대한 항균효과. Korean Society for

Biotechnology and Bioengineering Journal, 28: 74-79, 2013.

엄미선. 양하(Zingiber mioga)추출물의 화장품 약리활성 검증을 통한 화장품 소재로서의 유효성 평가. 한국응용과학기술 학회지, 37: 1088-1099, 2020.

양양, 이지안. 적양자 추출물의 항산화 및 항염 효능. 융합정보논문지, 9: 294-301, 2019.

양재찬, 장덕영. 붉나무 열매 분획추출물의 항산화 및 항균효과에 대한 연구. 문화와 융합, $41: 847-870,2019$.

윤현주, 조현조, 김진효, 박경훈, 길근환, 오진아, 조남준, 백민경. 님추출물의 in vitro 항돌연변이원성 및 유전독성 영향.

Journal of Applied Biological Chemistry, 57: 219-225, 2014.

윤현주, 최미선, 조현조, 한범석, 박경훈, 오진아, 조남준, 백민경. 님추출물의 경구투여에 따른 랫드의 신장독성 연구. 한

국환경농학회지, 33: 103-110, 2014.

조성미, 김정은, 이남호. 등수국 잎 추출물 유래 항염 및 항균 활성 성분. 대한화장품학회지, 46: 23-29, 2020.

정경태, 김병우. 오존화 올리브 오일의 세균과 Candida alicans에 대한 항미생물 활성 효과. 생명과학회지, 22: 223$230,2019$.

정효진, 현송화, 송바름, 이상래, 이윤주, 박수남. 자소엽 추출물의 항균 및 항산화 효과와 성분분석. 한국공업화학회지, 29: 716-725, 2018.

최서희, 김현주, 이범천, 문태기, 김남수. 항균성분의 지속력에 대한 인체적용 시험 평가. 대한화장품학회지, $39: 133-$ 140, 2013.

최선일, 이종석, 이사라, 조봉연, 최승현, 심완섭, 한웅호, 장길웅, 권희연, 최예은, 김종대, 이옥환. 산화적 스트레스가 유

도된 피부 섬유아세포에서 차풀 잎 추출물의 항산화 및 항노화 효능. 한국식품영양과학회지, 48: 933-942, 2019. 최정은, 문지선. 파슬리 추출물의 기능성 화장품 소재로서의 생리활성. 아시안뷰티화장품학술지, 15: 501-511, 2017. 현진아, 이지혜, 강은빈, 김현정, 김동인, 박가은, 곽기성, 안봉전. 님트리(Azadirachta indica)잎 에탄올추출물의 약리활

성 및 안티폴루션 효능 검증. 한국식품저장유통학회지, 27: 393-406, 2020. 


\section{中文摘要}

\section{印楝和聚合草提取物作为化妆品成分的生理活性}

康福希，柳敏貞 ${ }^{*}$

南部大学香匠美容学科, 光州, 韩国

目的: 近年来, 对天然材料的研究和开发正在积极进行。通过研究印楝和聚合草提取物的抗氧化、抗菌和抗真 菌活性，确认它们作为天然防腐剂和化妆品成分的适用性。方法: 分别以 $70 \%$ 乙醇为样品提取印楝和聚合草。 通过纸盘法证实了它们的抗氧化作用和抗皮肤相关细菌的抗菌和抗真菌活性。结果: 发现两种提取物均具有 高效的抗氧化作用, 但聚合草提取物显示出比印楝提取物更高的总多酚和类黄酮含量、更强的DPPH和ABTS 自由基清除能力以及更强大的超氧化物歧化酶 (SOD)活性。在测量了印楝和聚合草提取物对Staphylococcus epidermidis (S. epidermidis)、Staphylococcus aureus (S. aureus)、Propionibacterium acnes (P. acnes), Corynebacterium xerosis (C. xerosis)、Pityrosporum ovale (P. ovale)、Malassezia furfur (M. furfur), Candida albicans (C. albicans)、Trichophyton rubrum (T. rubrum) 和 Trichophyton mentagrophytes ( $T$. mentagrophytes)等与皮肤有关的菌, 证实了印楝提取物在 $5 \mathrm{mg} / \mathrm{mL}$ 浓度下, 对所有9种细菌的处理均显示出 清晰的区域，特别是在P. acnes、C. xerosis 和 T. mentagrophytes中分别观察到了 8、7 和7 mm的清晰区 域。聚合草提取物对所有9种细菌也显示出清晰的区域。特别是在P. acnes、C. xerosis、P. ovale、T. rubrum 和 T. mentagrophytes.中分别观察到了10、8、8、10和11 $\mathrm{mm}$ 的透明区域。从这些结果可以确认，聚合草提 取物具有比印楝提取物更高的抗菌和抗真菌作用, 因此, 印楝和聚合草提取物均对 $P$. acnes、C. xerosis 和 $T$. mentagrophytes 具有优异的抗菌作用。结论: 印楝和聚合草提取物对9种不同的皮肤相关细菌具有很好的抗氧化 作用以及抗菌和抗真菌作用。因此, 可以认为它们可用作天然防腐剂和化妆品成分。

关键词: 印楝，聚合草，抗氧化，抗菌，化妆品 